\title{
Acetic acid iontophoresis for the treatment of insertional Achilles tendonitis
}

\author{
Roger Lee Kilfoil Jr, ${ }^{1}$ Garry Shtofmakher, ${ }^{1}$ Gregory Taylor, ${ }^{2}$ Jessica Botvinick ${ }^{2}$
}

${ }^{1}$ New York College of Podiatric Medicine, Lake Grove New York, USA ${ }^{2}$ Department of Physical Therapy, New York College of Podiatric Medicine, New York, New York, USA

\section{Correspondence to} Garry Shtofmakher, gshtofmakher@nycpm.edu

Accepted 7 July 2014

\section{CrossMark}

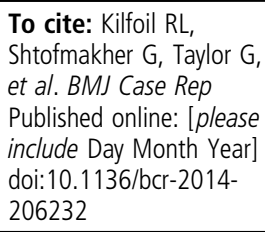

\section{DESCRIPTION}

Posterior heel pain is a constellation of pathologies that may include retrocalcaneal bursitis, insertional tendonitis, paratenonitis and tendonosis among others. ${ }^{1}$ The diagnosis of insertional Achilles tendonitis can be established clinically and radiographically and must be differentiated from retrocalcaneal bursitis and Haglund's deformity. ${ }^{2}$ Patients present clinically with chronic pain of gradual onset typically relieved when the patient is unshod and it may be painful to perform a single leg raise. ${ }^{3}{ }^{4}$ Calcaneal exostoses of the Achilles tendon may be evident on radiograph. Exostoses composed of calcium carbonate $\left(\mathrm{CaCO}_{3}\right)$ are exposed to the more chemically active acetate radical and replace the carbonate forming the blood soluble calcium acetate molecule $\left(\mathrm{Ca}\left(\mathrm{C}_{3} \mathrm{H}_{3} \mathrm{O}_{2}\right)_{2}\right){ }^{5}$

A treatment algorithm has been developed for posterior heel pain. ${ }^{3}$ Initial therapeutic modalities include physical therapy, orthotic management and anti-inflammatory medications. ${ }^{3}$ Iontophoresis has been suggested as an alternative to local corticosteroid injections. ${ }^{4}$ In a prospective study by Japour $e t$ al transdermal application of acetic acid through iontophoresis was shown to be an effective conservative treatment modality for heel pain. ${ }^{5}$

A 56-year-old man presented to a local podiatry clinic with intermittent posterior heel pain of several years duration that impeded the patients' activities of daily living: driving, prolonged walking and golfing. Gait analysis of the patient revealed an antalgic gait with early heel rise on the left with a short step length of the right. The patient required one-hand assist on ascent and descent of stairs. The patient described the pain as achy, with the left heel more painful than the right. Radiographs revealed the presence of retrocalcaneal exostoses (figure 1).

The patient had objective improvement in measures such as range of motion and gait deviations from manual therapy techniques such as kinesiotaping, myofascial release, deep tissue massage, joint mobilisation, ultrasound $\left(20 \%\right.$ at $\left.3.3 \mathrm{mHz}, 2.0 \mathrm{~W} / \mathrm{cm}^{2}\right)$ and home exercises/self-care consisting of dorsiflexion stretching, and ice massage, however the pain was still present.

The patient was then treated with iontophoresis therapy of 4\% acetic acid using phoresor PM900 at a setting of $2.0 \mathrm{~mA} \mathrm{DC}$ current for $20 \mathrm{~min}$ over five times in 2 weeks in which the positive electrode was overlying the skin of the midshaft of the fibula, and the negative electrode centred over the insertion of the Achilles tendon bilaterally (figure 2). The patient completed the Foot and Ankle Ability Measure, Activities of Daily Living Subscale, and the Lower Extremity Functional Scale, prior to and after the iontophoresis therapy (figures 3 and 4). After introduction of the iontophoresis therapy, the patient's pain scale improved. Following the third iontophoresis treatment, the patient no longer needed the rail during stair ascent and decent, and after the fifth therapy the patient was discharged from physical therapy, reaching his goal of decreased posterior heel pain.
Figure 1 Lateral and calcaneal axial radiographs of the foot and ankle bilaterally demonstrate a posterior

calcification of the Achilles tendon at the level of maximal tenderness.

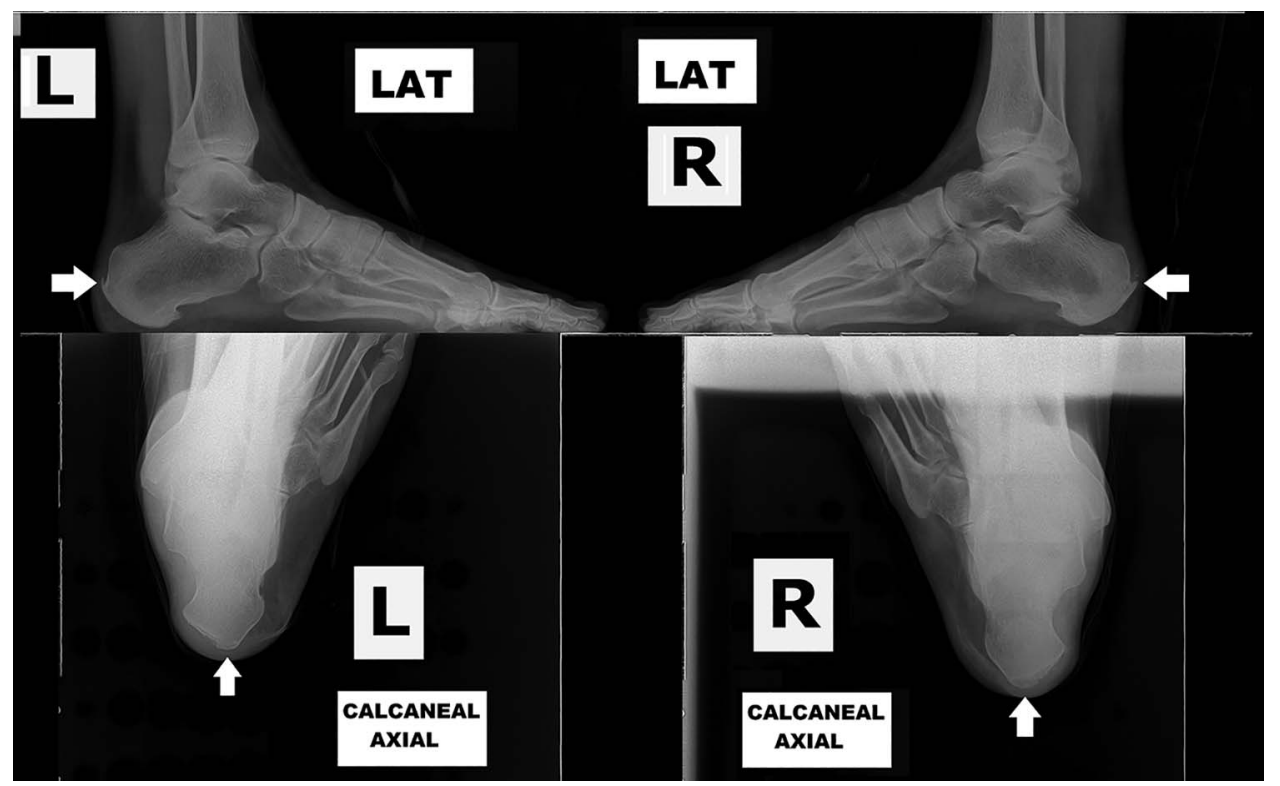




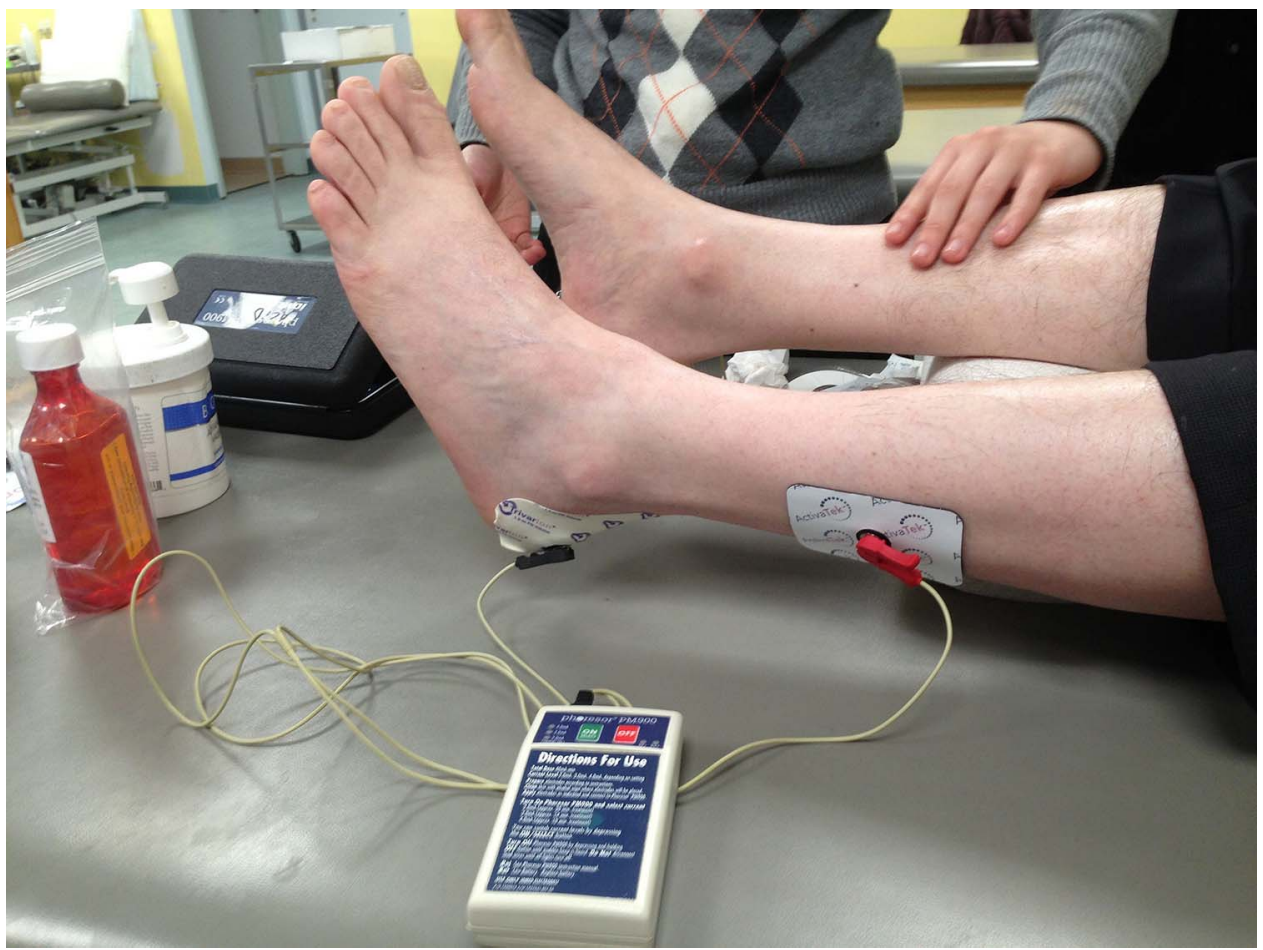

Figure 2 The transdermal iontophoresis with 4\% acetic acid on the negative electrode is placed on the skin over the insertion of the Achilles tendon. The positive electrode is placed on the lateral leg. The iontophoresis theory states that the negatively charged electrode will repel negatively charged ions through tissue.

\section{Prior to treatment}

\author{
Foot and Ankle Ablitty Measure (FAAM) \\ Activities of Daily Living Subscale \\ Page 2
}

\title{
After treatment
}

\author{
Foot and Ankle Ability Measure (FAAM) \\ Activities of Daily Living Subscale \\ Page 2
}

Because of your foot and ankle how much difficulty do you have with:

Because of your foot and ankle how much difficulty do you have with:

\begin{tabular}{|c|c|c|c|c|c|}
\hline & $\begin{array}{l}\text { No } \\
\text { Difficulty } \\
\text { at all }\end{array}$ & $\begin{array}{l}\text { Slight } \\
\text { Difficulty }\end{array}$ & $\begin{array}{l}\text { Moderate } \\
\text { Difficulty }\end{array}$ & $\begin{array}{l}\text { Extreme } \\
\text { Difficulty }\end{array}$ & $\begin{array}{l}\text { Uneble } \\
\text { to do }\end{array}$ \\
\hline Home responsibilities & $X$ & .1 & $u$ & $\cup$ & J \\
\hline Activities of daily living & ] & $x$ & [] & 0 & נ] \\
\hline Personal care & $x$ & ¿1 & 口 & ق & อ \\
\hline $\begin{array}{l}\text { Light to moderato work } \\
\text { (standing, walking) }\end{array}$ & Q & * & 口 & כ] & ] \\
\hline $\begin{array}{l}\text { Heavy work } \\
\text { (push/pulling, } \\
\text { climbing, carrying) }\end{array}$ & Q & U & $\gamma$ & 了 & J \\
\hline Recreational activities & ח & $\square$ & & כ & 7 \\
\hline
\end{tabular}

How would you rate your current level of function during you usual activities of daily living from 0 to 100 with 100 being your level of function prior to your foot or ankle problem and 0 being the inability to perform any of your usual daily activities.

$-8 \underline{0} .0 \%$

\begin{tabular}{|c|c|c|c|c|c|c|}
\hline & $\begin{array}{l}\text { No } \\
\text { Difficulty } \\
\text { at all }\end{array}$ & $\begin{array}{l}\text { Slight } \\
\text { Difficulty }\end{array}$ & $\begin{array}{c}\text { Moderate } \\
\text { Difficulty }\end{array}$ & $\begin{array}{l}\text { Extreme } \\
\text { Difficulty }\end{array}$ & $\begin{array}{l}\text { Uneble } \\
\text { to do }\end{array}$ & $\mathrm{N} / \mathrm{A}$ \\
\hline Home responsibilities & $x$ & $\therefore$ & $\sqcup$ & U & $J$ & i \\
\hline Activities of daily living & $x$ & :1 & [] & כ & i] & j \\
\hline Personal care & $\not$ & il & 口 & כ & コ & $z$ \\
\hline $\begin{array}{l}\text { Light to moderate work } \\
\text { (standing, walking) }\end{array}$ & $x$ & 7 & ח & ם & כ & 2 \\
\hline $\begin{array}{l}\text { Heavy work } \\
\text { (push/pulling, } \\
\text { climbing, carrying) }\end{array}$ & U & A & U & ב & 3 & $=$ \\
\hline Recreational activities & П & t & [ & 7 & ᄀ & \\
\hline
\end{tabular}

How would you rate your current level of function during you usual activities of daily living from 0 to 100 with 100 being your lovel of function prior to your foot or ankle problem and 0 being the inability to perform any of your usual daily activities.
living from 0 to 100 with 100 being yol of function prior to your fot

$-90.0 \%$

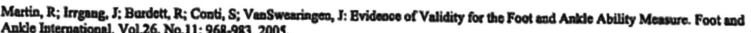

Figure 3 Foot and Ankle Ability Measure (FAAM) Activities of Daily Living Subscale prior to and after acetic acid iontophoresis therapy. Note the subjective decrease in difficulty in activities of daily living, light to moderate work, heavy work, and recreational activity. 
Prior to treatment

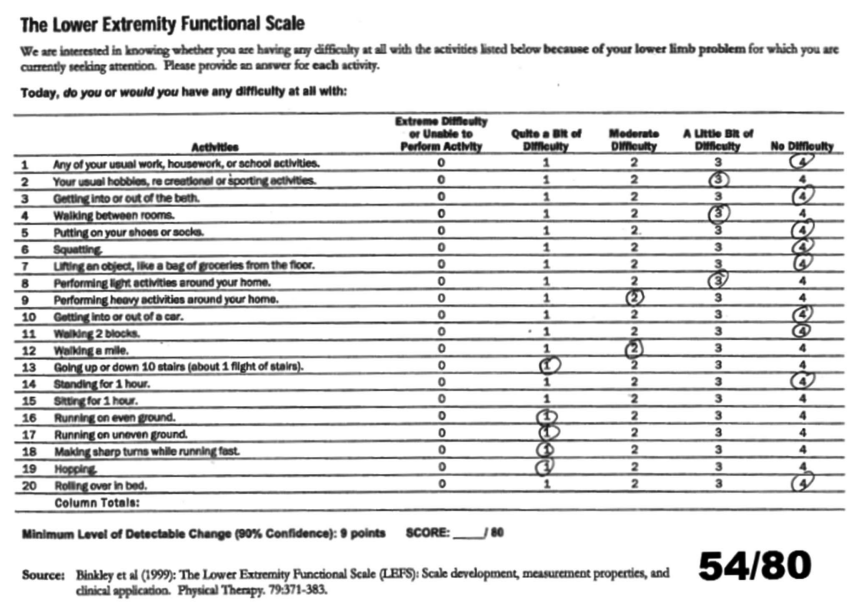

\section{After treatment}

\section{The Lower Extremity Functional Scale}

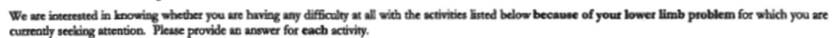

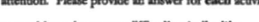

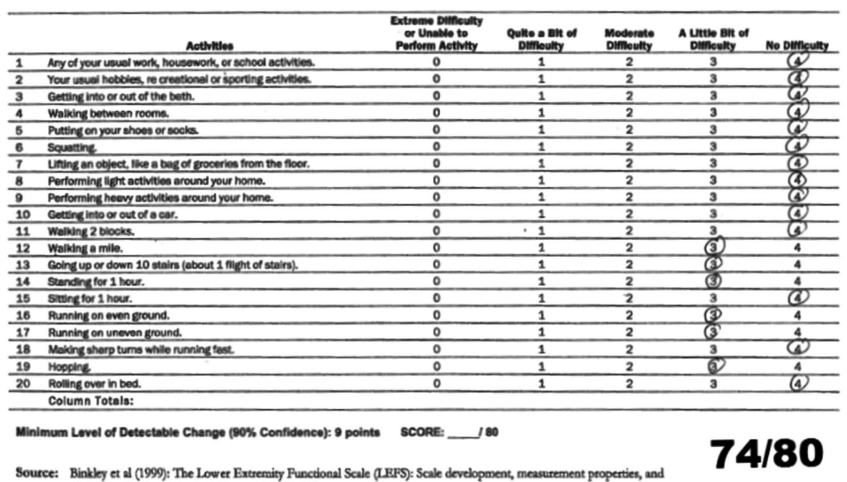

74/80

Figure 4 The Lower Extremity Functional Scale prior to Acetic Acid lontophoresis Therapy completed by the patient prior to and after the iontophoresis therapy. Note the subjective decrease in difficulty of running, ascending and descending stairs, walking a mile, and performing heavy activities around the home. The minimum level of detectable change increased from 54/80 to 74/80.

\section{Learning points}

- Iontophoresis can be utilised as an alternative to local corticosteroid injection for the treatment of posterior heel pain along with other conservative measures such as stretching, myofascial release and taping.

- The multifactorial nature of posterior heel pain can be attributed to increasing age, weight gain, biomechanical faults, medications and a myriad of systemic disorders. ${ }^{2}$

- Treatment algorithms suggest that after conservative treatment has been exhausted surgical intervention may consist of resection of the offending calcaneal spur and tendon debridement.
Competing interests None.

Patient consent Obtained.

Provenance and peer review Not commissioned; externally peer reviewed.

\section{REFERENCES}

1 Schepsis AA, Jones $H$, Haas AL. Achilles tendon disorders in athletes. Am J Sports Med 2002;30:287-305.

2 Tu P, Bytomski JR. Diagnosis of heel pain. Am Fam Physician 2011;84:909-16.

3 Aronow MS. Posterior heel pain (retrocalcaneal bursitis, insertional and noninsertional Achilles tendinopathy). Clin Podiatr Med Surg 2005;22:19-43.

4 Thomas JL, Christensen JC, Kravitz SR, et al. The diagnosis and treatment of heel pain: a clinical practice guideline-revision 2010. J Foot Ankle Surg 2010;49(3 Suppl): S1-19.

5 Japour CJ, Vohra R, Vohra PK, et al. Management of heel pain syndrome with acetic acid iontophoresis. J Am Podiatr Med Assoc 1999;89:251-7.

Copyright 2014 BMJ Publishing Group. All rights reserved. For permission to reuse any of this content visit

http://group.bmj.com/group/rights-licensing/permissions.

BMJ Case Report Fellows may re-use this article for personal use and teaching without any further permission.

Become a Fellow of BMJ Case Reports today and you can:

- Submit as many cases as you like

- Enjoy fast sympathetic peer review and rapid publication of accepted articles

- Access all the published articles

- Re-use any of the published material for personal use and teaching without further permission

For information on Institutional Fellowships contact consortiasales@bmjgroup.com

Visit casereports.bmj.com for more articles like this and to become a Fellow 